\section{Ku UNA Kamonu Eğitim Dergisi Kastamonu Education Journal}

Mayıs 2019 Cilt:27 Sayı:3

kefdergi.kastamonu.edu.tr
Başvuru Tarihi/Received: 18.06.2018

Kabul Tarihi/Accepted: 2.08.2018

DOI: $10.24106 /$ kefdergi.3164

\title{
Matematik Öğretmen Adaylarının Trigonometri Konusunda Kullandıkları Kanıt Şemalarının Öğrenme Stillerine Göre İncelenmesi ${ }^{1}$
}

\section{Investigations of Mathematics Teacher Candidates' Proof Schemes in Trigonometry According to Learning Styles}

\section{Öz}

\author{
Oya PEKTAŞ², Göksal BiLGici
}

Bu araştrrmada ilköğretim matematik öğretmeni adaylarının öğrenme stillerinin ve trigonometri konusunda tercih ettikleri kanıt şemalarının belirlenmesi ve bunların farklı değişkenler açısından incelenerek kanıt şemalarının öğrenme stillerine göre değişimini ortaya koymak amaçlanmıştr. Bu amaç doğrultusunda tarama yönteminin kullanıldığı bu araştırmada 2013-2014 eğitim öğretim yılında Kastamonu Üniversitesi Eğitim Fakültesi Illköğretim Bölümü Matematik Öğretmenliği Anabilim Dalında öğrenim gören 170 öğretmen adayı araştırmanın çalışma grubunu oluşturmuştur. Araştırmada veri toplama aracı olarak Kolb öğrenme stili envanteri ve Trigonometri İspat Envanteri (TiE) kullanılmıştr. Katılımcıların öğrenme stilleri, envantere verilen yanıtlara göre belirlenirken, kanıt şemaları betimsel analiz yöntemi ile belirlenmiştir. Araştırmadan elde edilen bulgulara göre katılımcılar arasında baskın olan öğrenme stilinin özümseyen olduğu ve aynı zamanda öğrenme stillerinin cinsiyete ve sınıf düzeyine göre farklılaşmadığı görülmüştür. Bununla birlikte kathlımcıların en çok analitik kanıt şemasını kullanmayı tercih ettiği ve kanıt yaparken kullandıkları kanıt şemalarının öğrenme stillerine göre farklılaşmadığı tespit edilmiştir.

Anahtar Kelimeler: öğrenme stili, kanıt şeması, matematik eğitimi, trigonometri

\section{Abstract}

This research aimed to determine the learning styles of elementary school mathematics teacher candidates and the proof schemes they preferred about trigonometry and to examine them in terms of different variables and to show the change according to the learning styles of the proof schemes. This study has been carried as a survey study. The participants of the study included 1st, 2nd, 3rd and 4th grade elementary school mathematics teacher candidates studying at Kastamonu University during the 2013-2014 academic year. Data were collected through Kolb learning style inventory and Trigonometry Proof Inventory. While the learning styles of the participants were determined according to the answers given in the inventory, teacher candidates' proof schemes were determined by means of descriptive analysis. Findings from the research showed that the assimilated learning was the most prevalent learning style among the participants and that learning styles did not differ according to gender and grade level. However, it was seen that analytic proof scheme was the most preferred proof scheme in trigonometry and that the proof schemes they preferred while proving did not differ according to learning styles.

Keywords: learning styles, proof scheme, mathematics education, trigonometry

1. Bu çalışma, birinci yazarın ikinci yazarın danışmanlığında gerçkeleştirmiş olduğu yüksek lisans tezinden üretilmiştir.

2. Milli Eğitim Bakanlığı, Kastamonu, Türkiye.;https://orcid.org/0000-0002-0222-9023

3. Kastamonu Üniversitesi, Eğitim Fakültesi, Kastamonu, Türkiye.; https://orcid.org/0000-0001-9964-5578

Atıf / Citation: Pektaş, O.,\& Bilgici, G. (2019). Matematik öğretmen adaylarının trigonometri konusunda kullandıkları kanıt şemalarının öğrenme stillerine göre incelenmesi. Kastamonu Education Journal, 27(3), 1347-1358. doi:10.24106/kefdergi.3164 


\section{Extended Summary}

As the most basic unit in mathematics (Mingus \& Grassl, 1999), mathematical proof holds an important place in mathematics (Hanna, 2000) just as mathematics holds a unique place in fundamental sciences. This is because everything new in mathematics is based on existing situations or foundations. Mathematicians, therefore, form new acceptable constructions by using mathematical proof. This provides the opportunity for mathematics to develop and grow in the positive direction (Mingus \& Grassl, 1999). Even if students do not believe in the necessity of mathematical proof, it is more important to establish how the students are ensured of the solution to a mathematical problem than being correct (İskenderoğlu, 2010). Studies that examine the relationship between learning styles and mathematical proof in literature are rather limited (Ören, 2007). In fact, there were not any trigonometry studies that examined the relationship between proof schemes and learning styles.

The aim of this study is to determine the learning styles and proof schemes of primary mathematics teacher education students, to examine them in terms of different variables, and to demonstrate the change of the proof schemes according to learning styles.

This study is a study conducted in the cross-sectional survey model from descriptive research methods. Descriptive studies are usually carried out to clarify a given situation, to make assessments in line with the standards, and to reveal possible associations between events (Çepni, 2014). Descriptive research identifies an existing situation as fully and carefully as possible. The most commonly used descriptive method is the survey study in the field of education (Büyüköztürk, Çakmak, Akgün, Karadeniz \& Demirel, 2012).

Target population of this study is composed of all candidate teachers who are enrolled in first, second, third and fourth year in the Department of Primary Mathematics Teacher Education in the Faculty of Education. The sampling of the research comes from the first, second, third, and fourth grade teacher candidates who are studying in Primary Mathematics Teacher Education Department in Kastamonu University in 2013-2014 academic year. Kolb learning style inventory and Trigonometry Proof Inventory (TPI) were used as data collection tools in the study. While the learning styles of the participants were determined according to the responses given in the inventory, the proof schemes were determined by means of descriptive analysis.

Findings from the research showed that, the predominant learning style was assimilating learning among the participants, that learning styles did not differ according to sex and class level. However, it was revealed that the participants preferred to use the most analytic proof scheme, and the proof schemas they used did not differ according to the learning styles. 


\section{Giriş}

Kanıt, matematik disiplininin ve matematikçilerin pratiğinin merkezi olarak düşünülmektedir (Knuth, 2002). CadwalladerOlsker (2011)'e göre matematiksel olarak kanıtın tanımı üzerinde ise tartısmalar devam etmektedir. En geniş anlamda, kanıt, belirli bir iddianın doğruluğunu ortaya koymak olarak düşünülebilir. Tall (1995)'a göre matematikte kanıtlar iki nedenden dolayı önemlidir:

- Açık hipotezlere dayanarak, bir kanıt belirli sonuçların mantıksal olarak izlendiğini gösterir.

- Bu gibi mantkksal sonuçlar, matematik teorilerini oluşturmak için kullanılabilir.

Bu tanımlarda yer verildiği gibi sonuçların mantkksal olarak izlenebilmesi, tüm süreç boyunca akıl yürütme (muhakeme etme) becerisi gerçekleştirildiğinde mümkün olabilecektir. Günümüzde kullanılmakta olan lise matematik dersi öğretim programına bakıldığında da, öğrencilere matematik öğrenme sürecinde akıl yürütme becerilerini geliştirmeleri için ortamlar hazırlanmasının gerekli olduğu ifade edilmektedir (MEB, 2013).

ABD'de de Ulusal Matematik Öğretmenleri Konseyi (NCTM), beş temel süreç standardından biri olarak "muhakeme ve kanıt" olgusunu belirleyerek kanıtın matematik eğitimindeki rolünün önemli olduğunu vurgulamıștır (NCTM, 2000). NCTM'ye göre ortaokul bitiminde, öğrenciler mantıksal çıkarımlarından oluşan argümanlar ile delilleri anlamalı ve üretmelidirler. Laborde (2000) da öğrencilerin akıl yürütme yeteneklerini geliştirmek için kanıtın bir araç olarak kullanabileceğini öne sürmüş ve öğrencilerin akıl yürütme becerilerini geliştirdikleri temel yollardan birinin matematiksel kanıtlar üretmek olduğunu ifade etmiştir. Hanna (1990)'ya göre kanıtın değeri sadece kanıtlananların doğruluğu ile ilgili değildir, aynı zamanda bunların arasındaki matematiksel ilişkilerin de ortaya konulmasıdır. Harel ve Sowder (1998)'e göre, sorgulama ve ikna etme, kanıtlama sürecinin iki alt sürecidir. Sorgulama, bir kişinin gözlemin gerçekliği hakkında kendi kuşkularını ortadan kaldırmaya çalışması şeklinde tanımlanırken, ikna etme ise bu gerçeklik hakkında başkalarını şüphelerini kaldırmaya ikna etmek anlamına gelir. Dolayısıyla, Harel ve Sowder (1998) bir kişinin kanıt şemasını "bu kişiyi sorgulatan ve ikna eden unsurlar" olarak tanımlamışlardır.

Alan yazın incelendiğinde, öğretmenlerin, öğretmen adaylarının ve öğrencilerin kanıta bakış açılarını, kanıt içselleştirmelerini ve kanıtlama süreçlerini ortaya koymaya çalışan çok sayıda araştırmaya rastlanmıştı (Jones, 1997; Harel ve Sowder, 1998; Almeida, 2000; Incikabı, 2013;Recio ve Godino, 2001; Knuth, 2002; Housman ve Porter, 2003; Solomon, 2006; Cusi ve Malara, 2007; Sarı, Altun ve Aşkar, 2007; İskenderoğlu, 2010). Öğrencilerin kanıt yaparken karşılaştıkları problemlerin altında yatan güçlüklerin nedenlerini belirlemeye yönelik çalışmalar, öğrencilerin sadece kanıt yaparken değil, kanıtın ne olduğunu bile anımsarken zorluk yaşadığını ortaya koymuştur (Chazan, 1993; Moore, 1994).

Kişinin kanıt şeması, matematiksel duruma dair hangi durumları/faktörleri belirlemesi gerektiği ve faktörlere/durumlara ikna olmasına/etmesine ilişkin kavramları kapsamaktadır (Dede ve Karakuş, 2014). Harel ve Sowder (1998) yedi kanıt şemasını dışa dayalı, deneysel ve analitik olmak üzere üç gruba ayırmışlardır:

- Dışa dayalı kanıt düzeni, öğretmen, ders kitabı gibi öğrencilerin dışında bulunan bir kaynağın yetkisine dayanan gerekçelendirmeyi içerir.

- Deneysel kanıt şeması sadece örneklere veya daha özel olarak çizimlere dayanan gerekçeleri içerir.

- Analitik kanıt şeması, resmi matematiksel deliller ile sonuçlanan ya da sonuçlanabilecek genel argümanlara ya da zihinsel operasyonlara dayanarak gerekçelendirmeyi içerir.

Kanıt sürecinde kullanılan kanıt şemaları öğrencilerin mevcut düşüncelerini ortaya koyduklarından dolayı (Dede ve Karakuş, 2014) öğrencilerin öğrenme stilleri ile ilişkisi bulunmaktadır. Öğrencilerin bilgiyi nasıl kazandıkları ve nasıl içselleştirdikleri ile ilgili tercihleri vardır. Bu yüzden aynı öğrenme işine öğrenciler farklı şekillerde yaklaşırlar. Kolb (1984)'un aktif öğrenme döngüsü içinde öğrenenlerin yeni bilgileri içselleştirmek için tercih ettikleri yöntem öğrenme stili olarak tanımlanmıştr. Kolb (1984)'a göre bilişsel stil ile öğrenme stili kavramları birbirinin yerine kullanılabilir. Öğrencilerin bir davranışın kazanılmasındaki yaklaşımları onların öğrenme stillerini oluşturur. Kolb (1981)'a göre öğrenenler kendi deneyimlerinden ve yaşantılarından öğrenirler ve bunun sonuçlarının değerlendirilmesi de güvenlidir. Yaşantıya dayalı öğrenme, kişisel öğrenme ve gelişim için seçim yöntemi olmuştur. Yaşantısal öğrenme, farklı eğitim seviyelerinde yaygın biçimde kullanılmaktadır. Böylelikle birbirlerine yakın öğrenme stili olan bireyler beraber hareket edebilirler (Kolb, 1981). Öğrenenlerin sahip oldukları bütün öğrenme stillerine uygun uyaranların verilmesi önemlidir (Brock ve Cameron, 1999). Böylece öğrenenler kendilerine uygun bir öğrenme süreci yaşarlar ve etkin problem çözme ve düşünme becerilerini bu süreç içinde geliştirirler (Sünbül, 2004).

Öğrenme stilleri ile kanıt arasındaki ilişkileri inceleyen çalışmalar oldukça sınırlı sayıdadır (Ören, 2007). Hatta trigonometri özelinde kanıt şemaları ile öğrenme stilleri arasındaki ilişkileri inceleyen bir çalışmaya rastlanmamıştr. Bu çalışma kanıt şemaları ve öğrenme stillerinin birlikte ele alındığı bir çalışma olmakla beraber, bu değişkenleri cinsiyet 
ve sınıf düzeyleri dikkate alınarak irdelemeyi de amaçlamıştır. Matematik eğitimcileri için öğrencilerin kanıt yapma süreçlerinde yaşadıkları zorlukları daha iyi anlayabilmeleri için öğrencilerin öğrenme stillerindeki farklııkları da göz önünde bulundurmaları oldukça önemlidir. Bu bakımdan bu araştırmanın öğretmenlere ve diğer araştırmacılara kaynak oluşturması düşünülmektedir.

Bu nedenle bu çalışmanın amacı ilköğretim matematik öğretmeni adaylarının öğrenme stillerini ve kanıt şemalarını belirlemek, bunları farklı değişkenler açısından incelemek ve kanıt şemalarının öğrenme stillerine göre değişimini ortaya koymak olarak belirlenmiştir. Bu amaç doğrultusunda araştırmanın cevap arayacağı sorular aşağıdaki gibidir:

- İlköğretim matematik öğretmen adayları hangi baskın öğrenme stiline sahiptir?

- İlköğretim matematik öğretmen adaylarının öğrenme stilleri cinsiyet ve sınıf değişkenlerine göre farklılaşmakta mıdır?

- Illköğretim matematik öğretmen adaylarının trigonometri konusunda kullandıkları kanıt şemaları nelerdir?

- İlköğretim matematik öğretmen adaylarının kullandıkları kanıt şemaları cinsiyet ve sınıf değişkenlerine göre farklılaşmakta mıdır?

- İlköğretim matematik öğretmen adaylarının kullandıkları kanıt şemalarının sahip oldukları öğrenme stillerine göre değişimi nasıldır?

\section{Yöntem}

Bu bölümde; araştırmanın modeli, çalışma grubu, araştırmada kullanılan veri toplama araçları, verilerin analizi ilgili konular üzerinde durulmuştur.

\section{Araştirmanın Modeli}

Bu çalışma betimsel araştırmalardan kesitsel tarama (survey) modelinde yürütülen bir çalışmadır. Betimlemeli çalışmalar genellikle verilen bir durumu aydınlatmak, bazı standartlar doğrultusunda değerlendirmeler yapmak ve olaylar arasında olası ilişkileri belirlemek için yürütülür (Çepni, 2014). Betimsel araştırmalar, verilen bir durumu olabildiğince tam ve dikkatli tanımlar. Eğitim alanındaki araştırmalarda en yaygın kullanılan betimsel yöntem tarama çalışmasıdır (Büyüköztürk, Çakmak, Akgün, Karadeniz ve Demirel, 2012). Fraenkel ve Wallen (2003) tarama araştırmalarını kesitsel, boylamsal ve geçmişe yönelik olmak üzere 3 kategoride incelemiştir. Kesitsel tarama modeli, belli bir grup yada gruplardan verinin bir seferde toplandığı ve zamanın verimli kullanıldığı bir araştırma modelidir (Fraenkel ve Wallen, 2003).

\section{Çalışma Grubu}

Araştırmanın çalışma grubunu 2013-2014 eğitim öğretim yılında Kastamonu Üniversitesi Eğitim Fakültesi İlköğretim Bölümü Matematik Öğretmenliği Anabilim Dalında öğrenim gören 170 öğretmen adayı oluşturmaktadır. 2013-2014 eğitim öğretim yılında Kastamonu Üniversitesi, Eğitim Fakültesi Illköğretim Bölümü Matematik Öğretmenliği Anabilim Dalında öğrenim gören öğretmen adaylarının sınıflara ve cinsiyete göre dağılımı Tablo 1'de verilmiştir.

Tablo 1. Matematik Öğretmenliği Anabilim Dalında öğrenim gören öğretmen adaylarının cinsiyetlerine ve sınıf düzeylerine göre dağılımı

\begin{tabular}{lcccccc}
\hline & & 1.Sınıf & 2.Sınıf & 3. Sınıf & 4. Inıf & Toplam \\
\hline \multirow{2}{*}{ Kız } & $N$ & 36 & 22 & 29 & 32 & 119 \\
\multirow{3}{*}{ Erkek } & $\%$ & 85,7 & 62,9 & 64,4 & 66,7 & 70 \\
& $N$ & 6 & 13 & 16 & 16 & 51 \\
\multirow{2}{*}{ Toplam } & $\%$ & 14,3 & 37,1 & 35,6 & 33,3 & 30 \\
& $N$ & 42 & 35 & 45 & 48 & 170 \\
\hline
\end{tabular}

\section{Veri Toplama Araçları}

Araştırmada veri toplama aracı olarak Kolb öğrenme stili envanteri ve Trigonometri İspat Sınavı (TiS) kullanılmıştır.

\section{Kolb Öğrenme Stili Envanteri}

Araştrrmada öğrencilerin öğrenme stillerini tespit etmek için Kolb (1984) tarafindan geliştirilen Kolb Öğrenme Stili envanteri kullanılmıştı. Aşkar ve Akkoyunlu (1993) tarafindan Türkçe'ye uyarlanan envanterde Kolb öğrenme stili modelinde ifade edilen 4 öğrenme stili tanımlanmıştr. Envanter, bireylerden kendi öğrenme stillerini en iyi tanımlayan 4 
öğrenme stilini sıraya dizmesini isteyen 4'er seçenekli 12 maddeden oluşmaktadır.

Kolb Öğrenme Stili modelinde dört öğrenme biçimi bulunmaktadır. Bunlar Somut Yaşant (SY), Yansıtıcı Gözlem (YG), Soyut Kavramsallaştırma (SK) ve Aktif Yaşant (AY)'dır. Ancak her bireyin öğrenme stilini belirleyen tek bir öğrenme biçimi bulunmamaktadır. Aslında bireylerin öğrenme stillerini yukarıda belirtilen öğrenme biçimlerinin bileşkesi belirlemektedir.

Aşkar ve Akkoyunlu (1993) tarafindan envanterin geçerlik ve güvenirlik çalışması Hacettepe Üniversitesi, Eğitim Fakültesi Öğretmenlik Sertifikası kurslarına katılan 62 kadın, 41 erkek toplam 103 yetişkine uygulanarak yapılmıştır. Elde edilen bulgulara göre somut yaşant için Cronbach alpha güvenirlik değeri 0,58, yansıttcı gözlem için 0,70 , soyut kavramsallaştırma için 0,71 , aktif yaşant için 0,65 , soyut-somut için 0,77 , aktif yansıtıcı için 0,76 olarak hesaplanmıştır.

Bu çalışma da Kolb öğrenme stili envanteri için Cronbach alpha iç tutarlılık güvenirlik değerine bakıldığında somut yaşant için 0,78 ; yansıtıcı gözlem için 0,73 ; soyut kavramsallaştırma için 0,77 aktif yaşant için 0,77 olduğu görülmüştür. Öğrenme biçimlerinin birleştirilmiş puanlarının güvenirlik değerlerine bakıldığında soyut-somut için Cronbach alpha 0,80; aktif yansıtıı için 0,83 çıktı̆ı̆ görülmüştür. Bulunan güvenirlik katsayıları ölçeğin hedef çalışma grubu üzerinde uygulanması için yeterli olan 0,70'den fazla bulunmuştur (Nunnally, 1978, s. 245).

Katılımcıların envantere verdiği cevaplar sonucunda 12 ile 48 arasında bir puan elde edilir. Bu puanların birleştirilmesi sonucunda öğrenme stilleri belirlenmektedir. Puanların birleştirilmesi;

SK-SY: soyut kavramsallaştırma- somut yaşant

AY-YG: aktif yaşant- yansıtıcı gözlem formülleri kullanılarak hesaplanır.

Puanların birleştirilmesi işleminin sonunda -36 ile +36 arasında değişen puanlar elde edildiği görülmektedir. SKSY'de elde edilen pozitif puan öğrenmenin soyut, negatif puan ise öğrenmenin somut olduğunu göstermektedir. Benzer şekilde AY-YG üzerinde elde edilen pozitif ve negatif puanlar öğrenmenin aktif ya da yansıticı olduğunu göstermektedir. Birleştirilmiş puanların elde edilmesi ile Şekil 1'de gösterilen diyagramda iki puanın kesiştiği nokta bireye en uygun olan öğrenme stilini vermektedir.

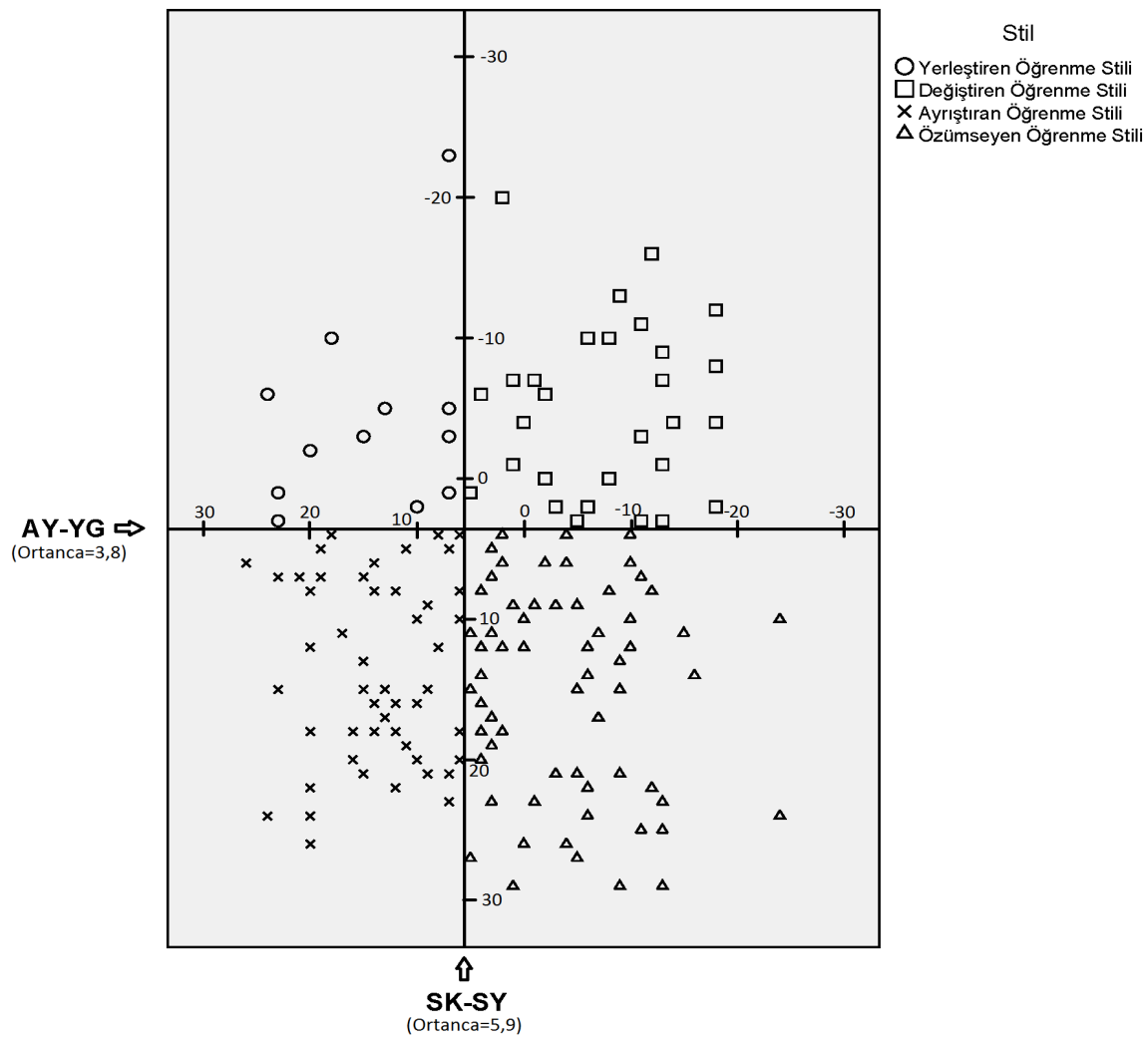

Şekil 1. Kolb Öğrenme Stili Diyagramı (Kolb, 1984 akt. Ekici, 2003)

Trigonometri İspat Envanteri

Bu envanter öğretmen adaylarının kanıt yapılarını ve kullandıkları kanıt tekniklerini ortaya koymak için tasarlanmış- 
tr. Öğrencilerden verilen trigonometrik ifadeleri kanıtlamaları istenmiştir.

Alanyazın taranarak öğrencilerin matematiksel muhakeme ve kanıt tekniklerini yapılan araştırmalar incelenmiştir (Miyazaki, 2000). Matematiksel kanıtla ilgili kitaplar ifade seçiminde göz önüne alınmıştır (Balcı, 2006; Kadıoğlu ve Kamali, 2015). Katlımcıların kanıt yapmalarını engelleyebilecek spesifik bilgi gerektiren trigonometri konularından mümkün olduğunca uzak durulmuştur. Ayrıca öğrencilerin kanıt yapıları hakkında bilgi edinebilmek için özellikle farklı yollarla kanıt edilebilecek maddeler tercih edilmiştir. Katlımcıların muhakeme düzeyleri hakkında daha güvenilir fikirler elde etmek için farklı güçlük düzeyinde maddeler seçilmiştir. Kapsam geçerliğini sağlamak için Matematik Eğitimi Anabilim dalında iki doçent ve bir yardımcı doçent öğretim üyesinin görüşleri göz önünde bulundurulmuştur. Trigonometri ispat envanterini oluşturmak üzere başlangıçta 8 trigonometrik ifade seçilmiştir. Bu ifadelerin hangilerinin hedef kitleye en uygun olduğunu belirlemek amacıyla uzmanlar tarafindan incelenmiş ve gerekli düzeltmeler uzman görüşleri doğrultusunda yapılmıştır. Araştırmada pilot çalışma olarak trigonometrik ifadeleri kanıt edip edemediklerini, soruların anlaşııp anlaşılmadığını, soruları çözmek için ne kadar sürenin makul olduğunu ve bütün öğrenciler tarafindan boş bırakılan soru olup olmadığını kontrol etmek için çalışma grubu dışında 29 ilköğretim matematik öğretmenliği öğrencisinden verilen 8 ifadeyi kanıt etmeleri istenmiştir. Pilot çalışma sonunda iki madde öğrencilerin çoğunluğu tarafindan anlaşılamadığı veya zor olduğu için envanterden çıkarılmıştı. Böylece 6 maddeden oluşan envanter esas uygulama için son halini almıştir.

\section{Verilerin Analizi}

Öğretmen adaylarının hangi öğrenme stiline sahip olduğu Healey ve Jenkins (2000) tarafindan açıklanan şekilde; öğrencilerin AY-YG puanları 3,8 puandan düşük olup olmamasına göre gruplandırılmış, SK-SY puanları ise 5,9 puandan düşük olmamasına göre gruplandırımıştır. Öğretmen adayının AY-YG puanına göre ve SK-SY puanına göre grubu bulunduktan sonra öğrenme stili belirlenmiştir.

Öğretmen adaylarının hangi kanıt şemalarını kullandığını belirlemek için öğrencilerin Trigonometri İspat Envanterinde istenen kanıtları yaparken en çok kullandıkları kanıt şeması bulunarak öğretmen adayının hangi kanıt şemasını baskın olarak kullandığı tespit edilmiştir.

Öğretmen adaylarının öğrenme stilleri ve kullandıkları kanıt şemaları belirlendikten sonra bağımsız değişkenlere göre dağılımlarının düzgün olup olmadığını kontrol etmek amacıyla SPSS 17 paket programı kullanılarak ki-kare () testleri uygulanmıştr.

\section{Bulgular}

\section{Öğretmen Adaylarının Öğrenme Stillerinin Cinsiyete Göre İncelenmesi}

İlköğretim matematik öğretmenliğinde okuyan öğretmen adaylarının öğrenme stillerinin cinsiyetlere göre dağıımı Tablo 2'de verilmiştir.

Tablo 2. Öğretmen adaylarının öğrenme stillerinin cinsiyete göre dağılımı

\begin{tabular}{lcccc}
\hline \multirow{2}{*}{ Öğrenme Stili } & & \multicolumn{2}{c}{ Cinsiyet } & Koplam \\
& & Kız & Erkek & \\
\hline \multirow{2}{*}{ Yerleştiren Öğrenme Stili } & $f$ & 8 & 4 & 12 \\
& Cinsiyete Göre \% & 6,7 & 7,8 & 7,1 \\
Değiştiren Öğrenme Stili & $f$ & 20 & 11 & 31 \\
& Cinsiyete Göre \% & 16,8 & 21,6 & 18,2 \\
Ayrıştiran Öğrenme Stili & $f$ & 36 & 18 & 54 \\
& Cinsiyete Göre \% & 30,3 & 35,3 & 31,8 \\
Özümseyen Öğrenme Stili & $f$ & 55 & 18 & 73 \\
& Cinsiyete Göre \% & 46,2 & 35,3 & 42,9 \\
\hline \multirow{2}{*}{ Toplam } & $f$ & 119 & 51 & 170 \\
& Cinsiyete Göre \% & 100 & 100 & 100 \\
\hline
\end{tabular}

Tablo 2 incelendiğinde her iki cinsiyet içinde özümseyen öğrenme stiline sahip öğrencilerin ağırlıkta olduğu görülmektedir. Bu öğrenme stilinde kı öğrencilerin oranının $(\% 46,2)$ erkek öğrencilerin oranına $(\% 35,3)$ göre daha yüksek çıktı̆ı bulunmuştur. Bu durumun aksine diğer öğrenme stillerinde ise erkek öğrencilerin oranının kız öğrencilere göre | Kastamonu Eğitim Dergisi, 27(3), 2019 | 
daha fazla olduğu tespit edilmiştir. Erkeklerin oranının ağırlıkta olduğu öğrenme stillerinde en fazla farkın ayrıştıran öğrenme stilinde (\% 5) olduğu en az farkın ise yerleştiren öğrenme stilinde (\% 1,1) olduğu görülmektedir.

İlköğretim matematik öğretmenliğinde okuyan öğretmen adaylarının öğrenme stillerinin cinsiyete göre farklılaşıp farklılaşmadığını belirlemek için yapılan Ki-Kare () testi sonuçları Tablo 3'de verilmiştir.

Tablo 3. Öğretmen adaylarının öğrenme stillerinin cinsiyete göre dağılımı için Ki-Kare testi sonuçları

\begin{tabular}{lccc}
\hline Istatistik & Değer & sd & $p$ \\
\hline Pearson Chi-Square & 1,785 & 3 &, 618 \\
Likelihood Ratio & 1,803 & 3 &, 614 \\
Linear-by-Linear Association & 1,292 & 1 &, 256 \\
$\mathrm{~N}$ & 170 & & \\
\hline
\end{tabular}

Tablo 3 incelendiğinde ilköğretim matematik öğretmenliğinde okuyan öğretmen adaylarının öğrenme stillerinin cinsiyete göre farklılaşmadığı görülmüştür $((3)=1,785 ; p>, 05)$.

Öğretmen Adaylarının Öğrenme Stillerinin Okudukları Sınıf Düzeyine Göre İncelenmesi

İlköğretim matematik öğretmenliğinde okuyan öğretmen adaylarının öğrenme stillerinin okudukları sınıf düzeyine göre dağılımı Tablo 4'te verilmiştir.

Tablo 4. Öğretmen adaylarının öğrenme stillerinin okudukları sınıf düzeyine göre dağıımı

\begin{tabular}{lcccccc}
\hline \multirow{2}{*}{ Öğrenme Stili } & & \multicolumn{3}{c}{ Sınıf } & \multicolumn{2}{c}{ Toplam } \\
\hline \multirow{2}{*}{ Yerleştiren Öğrenme Stili } & $f$ & 1 & 2 & 3 & 4 & 12 \\
& Sınıfa Göre \% & 7,1 &, 0 & 8,9 & 10,4 & 7,1 \\
Değiş̧tiren Öğrenme Stili & $f$ & 4 & 9 & 11 & 7 & 31 \\
& Sınıfa Göre \% & 9,5 & 25,7 & 24,4 & 14,6 & 18,2 \\
Ayrıştiran Öğrenme Stili & $f$ & 13 & 7 & 13 & 21 & 54 \\
& Sınıfa Göre \% & 31,0 & 20,0 & 28,9 & 43,8 & 31,8 \\
Özümseyen Öğrenme Stili & $f$ & 22 & 19 & 17 & 15 & 73 \\
& Sınıfa Göre \% & 52,4 & 54,3 & 37,8 & 31,3 & 42,9 \\
\hline \multirow{2}{*}{ Toplam } & $f$ & 42 & 35 & 45 & 48 & 170 \\
& Sınıfa Göre \% & 100,0 & 100,0 & 100,0 & 100,0 & 100,0 \\
\hline
\end{tabular}

Tablo 4 incelendiğinde birinci sınıfta okuyan öğretmen adaylarının en fazla özümseyen öğrenme stilinde (\% 52,4), en az ise yerleştiren öğrenme stilinde $(\% 7,1)$ yoğunlaştı̆̆ görülmektedir. İkinci sınıfta okuyan matematik öğretmenliği adaylarının yine benzer şekilde en fazla özümseyen öğrenme stiline $(\% 54,3)$ toplandıkları görülmesine rağmen yerleştiren öğrenme stilinde hiçbir ikinci sınıf öğretmen adayının olmadığı ortaya çıkmıştr. Üçüncü ve dördüncü sınıfta okuyan öğretmen adaylarında özümseyen öğrenme stiline sahip öğrencilerin oranının giderek azaldığı hatta dördüncü sınıfta okuyan öğretmen adayları arasında en fazla görülen öğrenme stilinin ayrıştıran öğrenme stili $(\% 43,8)$ olduğu görülmektedir. Diğer taraftan öğretmen adaylarının dört sınıf düzeyinde de en az yerleştiren öğrenme stiline sahip oldukları göze çarpan bir durumdur.

İlköğretim matematik öğretmenliğinde okuyan öğretmen adaylarının öğrenme stillerinin okudukları sınıf düzeyine göre farklılaşıp farklılaşmadığını belirlemek için yapılan Ki-Kare () testi sonuçları Tablo 5'de verilmiştir.

Tablo 5. Öğretmen adaylarının öğrenme stillerinin okudukları sınıf düzeyine göre dağılımı için Ki-Kare testi sonuçları

\begin{tabular}{lccc}
\hline İstatistik & Değer & sd & $p$ \\
\hline Pearson Chi-Square & 15,125 & 9 &, 088 \\
Likelihood Ratio & 17,704 & 9 &, 039 \\
Linear-by-Linear Association & 4,127 & 1 &, 042 \\
$N$ & 170 & & \\
\hline
\end{tabular}


Tablo 5 incelendiğinde ilköğretim matematik öğretmenliğinde okuyan öğretmen adaylarının öğrenme stillerinin sınıf düzeyine göre farklılaşmadığı görülmüştür $((9)=15,125 ; p>, 05)$.

İlköğretim matematik öğretmenliğinde okuyan öğretmen adaylarının kanıt yaparken kullandıkları kanıt şemalarının cinsiyetlere göre dağııımı Tablo 6'da verilmiştir.

\section{Öğretmen Adaylarının Kullandıkları Kanıt Şemalarının Cinsiyete Göre İncelenmesi}

Tablo 6. Öğretmen adaylarının kullandıkları kanıt şemalarının cinsiyete göre dağılımı

\begin{tabular}{lcccc}
\hline \multirow{2}{*}{ Kanıt Şemaları } & & \multicolumn{2}{c}{ Cinsiyet } & Toplam \\
& & Kız & Erkek & \\
\hline \multirow{2}{*}{ Dışsal Kanıt Şemaları } & Beklenen $f$ & 37,1 & 15,9 & 53,0 \\
& Cinsiyete Göre \% & $37,0 \%$ & $17,6 \%$ & $31,2 \%$ \\
& $f$ & 9 & 9 & 18 \\
Deneysel Kanıt Şemaları & Beklenen $f$ & 12,6 & 5,4 & 18,0 \\
& Cinsiyete Göre \% & $7,6 \%$ & $17,6 \%$ & $10,6 \%$ \\
& $f$ & 66 & 33 & 99 \\
Analitik Kanıt Şemaları & Beklenen $f$ & 69,3 & 29,7 & 99,0 \\
& Cinsiyete Göre \% & $55,5 \%$ & $64,7 \%$ & $58,2 \%$ \\
\hline \multirow{2}{*}{ Toplam } & $f$ & 119 & 51 & 170 \\
& Beklenen $f$ & 119,0 & 51,0 & 170,0 \\
& Cinsiyete Göre \% & $100,0 \%$ & $100,0 \%$ & $100,0 \%$ \\
\hline
\end{tabular}

Tablo 6 incelendiğinde ilköğretim matematik öğretmenliğinde okuyan öğrencilerde her iki cinsiyet içinde kanıt yaparken analitik kanıt şemalarını kullandıkları görülmektedir. Kanıt yaparken analitik kanıt şemalarını kullanan erkek öğrencilerin oranının \% 64,7 kız öğrencilerin oranına (\% 55,5) göre daha yüksek çıktığı bulunmuştur. Benzer durum kanıt yaparken deneysel kanıt şemalarını kullanan erkek öğrenciler (\% 17,6) ile kız öğrenciler $(\% 7,6)$ arasında da görülmektedir. Diğer taraftan kanıt yaparken dışsal kanıt şemalarını kullanan öğretmen adaylarında ise kız öğrencilerin oranının $(\% 37,0)$ erkek öğrencilerin oranına $(\% 17,6)$ göre daha yüksek çıktığı tespit edilmiştir. Kız ve erkek öğretmen adayları için kanıt yaparken en az deneysel kanıt şemalarını tercih ettikleri söylenebilir.

İlköğretim matematik öğretmenliğinde okuyan öğretmen adaylarının kanıt yaparken kullandıkları kanıt şemalarının cinsiyete göre farklılaşıp farklılaşmadığını belirlemek için yapılan Ki-Kare () testi sonuçları Tablo 7'de verilmiştir.

Tablo 7 Öğretmen adaylarının kullandıkları kanıt şemalarının cinsiyete göre dağılımı için Ki-Kare testi sonuçları

\begin{tabular}{lccc}
\hline İstatistik & Değer & sd & $p$ \\
\hline Pearson Chi-Square & 8,230 & 2 &, 016 \\
Likelihood Ratio & 8,419 & 2 &, 015 \\
Linear-by-Linear Association & 3,529 & 1 &, 060 \\
$N$ & 170 & & \\
\hline
\end{tabular}

Tablo 7 incelendiğinde ilköğretim matematik öğretmenliğinde okuyan öğretmen adaylarının kanıt yaparken kullandıkları kanıt şemalarının cinsiyete göre farklılaştığı görülmüştür $((2)=8,230 ; p<, 05)$. Farkın Tablo 5 'teki hangi hücrelerden kaynaklandığına bakıldığında değerine en çok katkının kanıt yaparken dışsal kanıt şemalarını kullanan erkeklerden (beklenen değer 15,9 ve ye katkı ) olduğu, daha sonra en çok katkının deneysel kanıt şemalarını kullanan erkeklerden (beklenen değer 5,4 ve ye katkı ) olduğu görülmüştür. Bu farka en az katkının ise analitik kanıt şemalarını kullanan kız öğrencilerden ) kaynaklandığı tespit edilmiştir.

\section{Öğretmen Adaylarının Kullandıkları Kanıt Şemalarının Okudukları Sınıf Düzeyine Göre İncelenmesi}

İlköğretim matematik öğretmenliğinde okuyan öğretmen adaylarının kanıt yaparken kullandıkları kanıt şemalarının okudukları sınıf düzeyine göre dağılımı Tablo 8'de verilmiştir. 
Tablo 8. Öğretmen adaylarının kullandıkları kanıt şemalarının okudukları sınıf düzeyine göre dağılımı

\begin{tabular}{|c|c|c|c|c|c|c|}
\hline \multirow{2}{*}{ Kanıt şemaları } & & \multicolumn{4}{|c|}{ Sinıf } & \multirow{2}{*}{ Toplam } \\
\hline & & 1 & 2 & 3 & 4 & \\
\hline \multirow{3}{*}{ Dışsal Kanıt Şemaları } & $f$ & 23 & 13 & 9 & 8 & 53 \\
\hline & Beklenen $f$ & 13,1 & 10,9 & 14,0 & 15,0 & 53,0 \\
\hline & Sınıfa Göre \% & 54,8 & 37,1 & 20,0 & 16,7 & 31,2 \\
\hline \multirow{3}{*}{ Deneysel Kanıt Şemaları } & $f$ & 3 & 1 & 13 & 1 & 18 \\
\hline & Beklenen $f$ & 4,4 & 3,7 & 4,8 & 5,1 & 18,0 \\
\hline & Sınıfa Göre \% & 7,1 & 2,9 & 28,9 & $2,1 \%$ & 10,6 \\
\hline \multirow{3}{*}{ Analitik Kanıt Şemaları } & $f$ & 16 & 21 & 23 & 39 & 99 \\
\hline & Beklenen $f$ & 24,5 & 20,4 & 26,2 & 28,0 & 99,0 \\
\hline & Sınıfa Göre \% & 38,1 & 60,0 & 51,1 & $81,3 \%$ & 58,2 \\
\hline \multirow{3}{*}{ Toplam } & $f$ & 42 & 35 & 45 & 48 & 170 \\
\hline & Beklenen $f$ & 42,0 & 35,0 & 45,0 & 48,0 & 170,0 \\
\hline & Sınıfa Göre \% & 100,0 & 100,0 & 100,0 & 100,0 & 100,0 \\
\hline
\end{tabular}

Tablo 8 incelendiğinde birinci sınıfta okuyan öğretmen adaylarının kanıt yaparken en fazla dışsal kanıt şemalarını (\% 54,8), tercih ettikleri görülmektedir. Diğer sınıflarda okuyan matematik öğretmenliği adaylarının ise en fazla analitik kanıt şemalarına yoğunlaşttkları ortaya çıkmıştır. Birinci $(\% 7,1)$, ikinci $(\% 2,9)$ ve dördüncü $(\% 10,6)$ sınıfta okuyan öğretmen adaylarının kanıtlarında en az deneysel kanıt şemalarıı tercih etmelerine rağmen üçüncü sınıfta $(\% 20,0)$ okuyan öğretmen adaylarının en az dışsal kanıt şemasını tercih ettikleri ortaya çıkmıştı. Analitik kanıt şemasına en fazla dördüncü sınıftaki matematik öğretmenliği adaylarının (\% 81,3), deneysel kanıt şemasına en fazla üçüncü sınıftaki matematik öğretmenliği adaylarının (\% 28,9) ve dışsal kanıt şemasına ise en fazla birinci sınıftaki matematik öğretmenliği adaylarının $(\% 54,8)$ yoğunlaşması bir diğer bulgu olarak karşımıza çıkmaktadır.

İlköğretim matematik öğretmenliğinde okuyan öğretmen adaylarının kanıt yaparken kullandıkları kanıt şemalarının okudukları sınıf düzeyine göre farklılaşıp farklılaşmadığını belirlemek için yapılan Ki-Kare () testi sonuçları Tablo 9'da verilmiştir.

Tablo 9. Öğretmen adaylarının kullandıkları kanıt şemalarının okudukları sınıf düzeyine göre dağıımı için Ki-Kare testi sonuçları

\begin{tabular}{lccc}
\hline Istatistik & Değer & sd & $p$ \\
\hline Pearson Chi-Square & 40,600 & 6 &, 000 \\
Likelihood Ratio & 37,966 & 6 &, 000 \\
Linear-by-Linear Association & 17,287 & 1 &, 000 \\
$N$ & 170 & & \\
\hline
\end{tabular}

Tablo 9 incelendiğinde ilköğretim matematik öğretmenliğinde okuyan öğretmen adaylarının kanıt yaparken kullandıkları kanıt şemalarının okudukları sınıf düzeyine göre farklılaştğı görülmüştür $((6)=40,600 ; p<, 05)$. illköğretim matematik öğretmenliğinde okuyan öğretmen adaylarının kanıt yaparken tercih ettikleri kanıt şemaları türlerinin okudukları sınıf düzeyine göre farklılaşmasının hangi hücrelerden kaynaklandığına bakıldığında değerine en çok katkının kanıt yaparken deneysel kanıt şemalarını kullanan üçüncü sınıfta okuyan öğrencilerden ( beklenen değer 4,8 ve ye katkı) olduğu, daha sonra en çok katkının dışsal kanıt şemalarını kullanan birinci sınıflardan (beklenen değer 13,1 ve ye katkı ) olduğu tespit edilmiştir. Ortaya çıkan bu farka en az katkının ise deneysel kanıt şemalarını kullanan birinci sınıf öğretmen adaylarından (beklenen değer 4,4 ve ye katkı ) olduğu görülmüştür.

Öğretmen Adaylarının İspat Yaparken Kullandıkları Kanıt Şemalarının Sahip Oldukları Öğrenme Stiline Göre İncelenmesi

İlköğretim matematik öğretmenliği anabilim dalında okuyan öğretmen adaylarının kanıt yaparken kullandıkları kanıt şemalarının sahip oldukları öğrenme stillerine göre dağılımı Tablo 10'da verilmiştir. 
Tablo 10. Öğretmen adaylarının kanıt yaparken kullandıkları kanıt şemalarının sahip oldukları öğrenme stiline göre dağılımı

\begin{tabular}{|c|c|c|c|c|c|}
\hline \multirow[t]{2}{*}{ Öğrenme Stili } & & \multicolumn{3}{|c|}{ Kanıt Şeması } & \multirow[b]{2}{*}{ Toplam } \\
\hline & & $\begin{array}{c}\text { Dışsal Kanıt } \\
\text { Şemaları }\end{array}$ & $\begin{array}{c}\text { Deneysel Kanıt } \\
\text { Şemaları }\end{array}$ & $\begin{array}{c}\text { Analitik Kanıt } \\
\text { Şemaları }\end{array}$ & \\
\hline \multirow{2}{*}{ Yerleştiren Öğrenme Stili } & $\mathrm{f}$ & 2 & 2 & 8 & 12 \\
\hline & Kanıt Şemasına Göre \% & 3,8 & 11,1 & 8,1 & 7,1 \\
\hline \multirow{2}{*}{ Değiştiren Öğrenme Stili } & $f$ & 8 & 4 & 19 & 31 \\
\hline & Kanıt Şemasına Göre \% & 15,1 & 22,2 & 19,2 & 18,2 \\
\hline \multirow{2}{*}{ Ayrıştıran Öğrenme Stili } & $f$ & 16 & 8 & 30 & 54 \\
\hline & Kanıt Şemasına Göre \% & 30,2 & 44,4 & 30,3 & 31,8 \\
\hline \multirow{2}{*}{ Özümseyen Öğrenme Stili } & $f$ & 27 & 4 & 42 & 73 \\
\hline & Kanıt Şemasına Göre \% & 50,9 & 22,2 & 42,4 & 42,9 \\
\hline \multirow{2}{*}{ Toplam } & $f$ & 53 & 18 & 99 & 170 \\
\hline & Kanıt Şemasına Göre \% & 100 & 100 & 100 & 100 \\
\hline
\end{tabular}

Tablo 10 incelendiğinde kanıt yaparken dışsal kanıt şemalarını kullanan öğretmen adaylarının en fazla özümseyen öğrenme stiline $(\% 50,9)$ sahip olduğu en az ise yerleştiren öğrenme stiline $(\% 3,8)$ sahip olduğu görülmektedir. Kanıtlarında deneysel kanıt şemalarını kullanan öğretmen adaylarının ise en fazla ayrıştıran öğrenme stiline sahip olduğu (\% $44,4)$ en az ise yerleştiren öğrenme stiline $(\% 11,1)$ sahip olduğu tespit edilmiştir. Kanıtlarında analitik kanıt şemalarını kullanan matematik öğretmenliği öğrencilerinin en fazla özümseyen öğrenme stiline $(\% 42,4)$ sahip olduğu en az ise yerleştiren öğrenme stiline $(\% 8,1)$ sahip olduğu tablodan elde edilen diğer bir bulgu olarak karşımıza çıkmaktadır.

İlköğretim matematik öğretmenliğinde okuyan öğretmen adaylarının öğrenme stillerinin kanıt yaparken kullandıkları kanıt şemalarına göre farklılaşıp farkılış̧madığını belirlemek için yapılan Ki-Kare () testi sonuçları Tablo 11'de verilmiştir.

Tablo 11. Öğretmen adaylarının kullandıkları kanıt şemalarının öğrenme stillerine göre dağılımı için Ki-Kare testi sonuçları

\begin{tabular}{lccc}
\hline İstatistik & Değer & sd & $p$ \\
\hline Pearson Chi-Square & 5,484 & 6 &, 483 \\
Likelihood Ratio & 5,833 & 6 &, 442 \\
Linear-by-Linear Association & 1,337 & 1 &, 248 \\
$N$ & 170 & & \\
\hline
\end{tabular}

Tablo 11'e bakıldığında ilköğretim matematik öğretmenliğinde okuyan öğretmen adaylarının öğrenme stillerinin kanıt yaparken tercih ettikleri kanıt şemalarına göre farklılaşmadığı görülmüştür ((9)=15,125; $p>, 05)$.

\section{Tartışma ve Sonuç}

Araştırmanın birinci alt problemine göre araştırmaya katılan öğretmen adaylarının sahip oldukları öğrenme stilleri ve bu stillerin cinsiyet ve sınıf değişkenine göre değişimi araştrılımıştır. Araştırmadan elde edilen bulgulara göre araştırmaya katılan 170 öğretmen adayının 73'ünün $(\% 42,9)$ özümseyen öğrenme stiline sahip olduğu belirlenmiştir. Benzer sonuç Pehlivan (2010), Altun (2016) ve Tufan (2016) tarafindan yapılan çalışmalarda da görülmüştür. Bu araştırmalarda katılımcılar arasında baskın olarak görünen öğrenme stilinin özümseyen öğrenme stili olduğu sonucuna ulaşılmıştır. Bu araştırmada da baskın olan öğrenme stilinin özümseyen olması seçilen çalışma grubunun demografik yapısından kaynaklandığı düşünülebilir. Araştırmanın çalışma grubunu sadece matematik öğretmen adaylarıın oluşturduğu göz önünde bulundurulursa, bu öğretmen adaylarının matematiğin doğasından kaynaklanan mantıksal çıkarım yapma ve bunları bir bütün haline sunma yeteneklerinin gelişmiş olduğu söylenebilir.

Araştırmaya katılan öğretmen adaylarının öğrenme stillerinin cinsiyete ve sınıf değişkenine bağlı olarak değişip değişmediğini incelemek için yapılan Ki-Kare () testi sonuçlarına göre öğrenme stillerinin iki değişkene göre de farklılaşmadığı sonucuna ulaşılmıştır. Benzer sonuçlara Köroğlu (2015), Altun (2016) ve Tufan (2016) tarafindan yapılan çalışmalarda da ulaşılmıştır. Bu çalışmalar arasında sadece Altun (2016) tarafindan yapılan çalışma da öğrenme stillerinin sınıf sevilerine göre istatistiksel olarak değiştiği görülmüştür. Bu araştırmada öğrenme stillerinin sınıf seviyesine göre değişiklik göstermemesi, seçilen çalışma grubunu aynı anabilim dalından olmasından ve sınıf düzeyine göre öğrenme stillerinin birbirine yakın olarak dağılım göstermesinden kaynaklandığı düşünülebilir. 
Araştırmanın üçüncü alt probleminde öğretmen adaylarının trigonometri konusunda kullandıkları kanıt şemaları belirlenmeye çalışımıştır. Araştırmadan elde edilen bulgulara göre araştırmaya katılan 170 öğretmen adayının $99^{\prime}$ unun $(\% 58,2)$ analitik kanıt şemasına sahip olduğu belirlenmiştir. Benzer sonuç Housman ve Porter (2003) ve İskenderoğlu (2010) yapmış oldukları çalışmalarda da görülmüştür. Ancak bu sonucun aksine Cusi ve Malara (2007) ve Ören (2007) tarafindan yapılan çalışmalarda katılımcıların en azının analitik kanıt şemalarına sahip oldukları belirlenmiştir. Bu çaIışmalardan Cusi ve Malara'nın (2007) çalışmasında çalışma grubu olarak sadece 4.sınıf matematik öğretmen adayları, Ören'in (2007) çalışmasında ise 10.sınıf öğrencileri seçilmiştir. Sınıf düzeyinde mevcut araştırmanın çalışma grubunda yer alan 4.sınıf 99 öğretmen adayının 39'unun $(\% 81,3)$ da analitik kanıt şemasını kullandığı tespit edilmiştir.

Araştırmanın dördüncü alt problemine göre araştırmaya katılan öğretmen adaylarının kullandıkları kanıt şemalarının cinsiyete ve sınıf değişkenine bağlı olarak değişip değişmediğini incelemek için yapılan Ki-Kare () testi sonuçlarına göre kanıt şemalarının iki değişkene göre de farklılaştğı sonucuna ulaşılmıştır. Bu araştırmada dışsal ve deneysel kanıt şemalarını kullanan erkek öğretmen adaylarının, analitik kanıt şemalarını kullanan kız öğretmen adaylarının farklılığa yol açthğı görülmüştür. Bu sonuç Ören'in (2007) yapmış olduğu çalışma ile uyumlu değildir; çünkü araştırmada kız öğrencilerin deneysel kanıt şemasını daha çok kullandığı sonucuna ulaşılııştr. Sınıf değişkenine göre ise farklı sınıf düzeyinde öğrenim gören öğrencilerin değişikliğe neden olduğu araştırmada bulunmuştur. Bu sonuç ìskenderoğlu'nun (2010) yapmış olduğu çalışmanın sonuçları ile uyumludur.

Araştırmanın beşinci ve son alt probleminde araştırmaya katılan öğretmen adaylarının kullandıkları kanıt şemaları ile sahip oldukları öğrenme stilleri arasındaki ilişki belirlenmiştir. Yapılan Ki-Kare () testi sonuçlarına göre kanıt şemalarının öğrenme stillerine göre farklılaşmadığı sonucuna ulaşılmıştır. Bu farklılaşmayı inceleyen alan yazında bir çalışma bulunmamaktadır.

\section{4. Öneriler}

Bu araştırmada öğretmen adaylarının sahip oldukları öğrenme stilleri ve baskın olarak tercih ettikleri kanıt şemalarının cinsiyet ve sınıf değişkenine göre değişimi araştıılmıştır. Bu çalışma bulguları Trigonometri konuları üzerinden elde edilmiş olup matematik kapsamında yer alan diğer konular üzerinde de benzer araştırmaların yapılması bu araştırmanın sonuçlarının yordanması bakımından katkı sağlayıcı olacaktır.

Yapılan araştırmanın katılımcılarını öğretmen adayları oluşturmaktadır. Farklı çalışma gruplarıyla (öğretmen, lise öğrencileri v.b.) yapılacak benzer doğaya sahip çalışmaların bu araştırmadan elde edilen bulguların test edilmesi ve nedenlerinin ortaya konması bakımdan önemli olacağı düşünülmektedir.

Bu çalışmada öğrencilerin öğrenme sitilleri ve kullandıkları kanıt şemaları ilişkilendirilmeye çalışılmıştır. Bulguların geçerliğinin daha geniş örneklem üzerinde ve daha kapsamlı konular içeren çalışmalarla test edilmesinin yararlı olacağı düşünülmektedir. Ayrıca öğrencilerin kullandıkları veya kullanmayı tercih ettikleri kanıt şemaları daha detaylı bir şekilde araştrılarak tercihlerine ait nedenler ortaya konulabilir. Dahası yapılacak başka çalışmalar ile öğrencilerin matematiksel kanıt yaparken yaşadıkları olası zorlukların saptanması mümkün olabilecektir.

Öğretmen adaylarının öğrenme sitilleri ve kullandıkları kanıt şemaları üzerine etkili olabilecek unsurların (lisans aldıkları dersler ve derslerde yer verilen kanıt şemaları, matematik öz yeterliği, matematiğe yönelik tutum gibi) araştırılmasının öğretmen adaylarının yaşayabileceği zorlukların giderilmesinde katkı sağlayacağı düşünülmektedir.

\section{Kaynakça}

Almeida, D. A. (2000). Survey of Mathematics Undergraduates' Interaction With Proof: Some Implications for Mathematics Education, International Journal of Mathematical Education in Science and Technology, 31(6), 869-890.

Altun, H. (2016). İlköğretim matematik öğretmenliği lisans öğrencilerinin türev konusundaki akademik başarıları ile öğrenme stilleri arasındaki ilişkilerin incelenmesi. Yayınlanmamış doktora tezi. Dokuz Eylül Üniversitesi, Eğitim Bilimleri Enstitüsü, İzmir.

Aşkar, P., ve Akkoyunlu, B. (1993). Kolb öğrenme stili envanteri. Eğitim ve Bilim, 17(87).

Balcı, M. (2006). Matematik Analiz 1.Ankara: Palme Yayıncılık.

Brock, K. L., \& Cameron, B. J. (1999). Enlivening political science courses with Kolb's learning preference model. Political Science \& Politics, 32(02), 251-256.

Büyüköztürk, S., Kiliç Çakmak, E., Akgün, Ö. E., Karadeniz, S., ve Demirel, F. (2012). Bilimsel Araşttrma Yöntemleri (18. Baski). Ankara: Pegem Akademi Yayımcılık.

CadwalladerOlsker, T. (2011). What do we mean by mathematical proof?. Journal of Humanistic Mathematics,1(1), 33-60.

Chazan, D. (1993). 'High school geometry students' justification for their views of empirical evidence and mathematical proof', Educational Studies in Mathematics 24(4), 359-387.

Cusi, A., ve Malara, N. (2007). Proofs problems in elementary number theory: Analysis of trainee teachers' productions. In Proceedings of the Fifth Conference of the European Society for Research in Mathematics Education (pp. 591-600). 
Çepni, S. (2014). Araştırma ve proje çalışmalarına giriş. (7. Baskı). Trabzon: Celepler Matbaacılık.

Dede, Y., ve Karakuş, F. (2014). Matematiksel ispat kavramına pedagojik bir bakış: Kuramsal bir çalışma. Adıyaman Üniversitesi Eğitim Bilimleri Dergisi, 4(2), 47-71.

Ekici, G. (2003). Öğrenme stiline dayalı öğretim ve biyoloji dersi öğretimine yönelik ders planı örnekleri. (1. Baskı) Ankara: Gazi Kitabevi. Fraenkel, J. R., ve Wallen, N. E. (2003). Observation and interviewing. How to design and evaluate research in education, 5, $455-463$. Hanna, G. (1990). Some pedagogical aspects of proof. Interchange, 21(1), 6-13.

Hanna, G. (2000). Proof, explanation and exploration: An overview. Educational studies in mathematics, 44(1), 5-23.

Harel, G., ve Sowder, L. (1998). Students' proof schemes: Results from exploratory studies. Research in collegiate mathematics education III, 234-283.

Healey, M., \& Jenkins, A. (2000). Kolb's experiential learning theory and its application in geography in higher education. Journal of geography, 99(5), 185-195.

Housman, D., ve Porter, M. (2003). Proof schemes and learning strategies of above-average mathematics students. Educational Studies in Mathematics, 53(2), 139-158.

Incikabı, L. (2013). illköğretim matematik öğretmenliği programı öğrencilerinin mantıksal argümanları kanıtlama yöntemlerinin incelenmesi. Adıyaman Üniversitesi Sosyal Bilimler Enstitüsü Dergisi, 12, 129-148.

İskenderoğlu, T. (2010). İlköğretim matematik öğretmeni adaylarının kanıtlamayla ilgili görüşleri ve kullandıkları kanıt şemaları. Yayınlanmamış doktora tezi, Karadeniz Teknik Üniversitesi Fen Bilimleri Enstitüsü, Trabzon.

Jones, K. (1997). Student-Teachers' Conceptions of Mathematical Proof, Mathematics Education Review, 9, 16-24.

Kadıoğlu, E. ve Kamali, M. (2015). Genel Matematik. Erzurum: Kültür Eğitim Vakfi Yayınları.

Knuth, E. J. (2002). Teachers' conceptions of proof in the context of secondary school mathematics. Journal of Mathematics Teacher Education, 5(1), 61-88.

Kolb, D. A. (1981). Learning styles and disciplinary differences. The modern American college, 1, $232-255$.

Kolb, D.A., (1984), Experiential Learning. Prentice-Hall.Inc., New Jersey.

Köroğlu, M. (2015). Öğretmen adaylarının özel alan yeterlikleri ile öğrenme stilleri arasındaki ilişkinin incelenmesi. Yayınlanmamış yüksek lisans tezi, Ahi Evran Üniversitesi Sosyal Bilimler Enstitüsü, Kırşehir.

Laborde, C. (2000). Dynamic geometry environments as a source of rich learning contexts for the complex activity of proving. Educational Studies in Mathematics, 44(1), 151-161.

Milli Eğitim Bakanlığı (MEB) (2013). Ortaokul matematik dersi (5-8.sınıflar) öğretim programı. Ankara.

Mingus, T. T. Y.ve Grassl, R. M. (1999). Preservice teacher beliefs about proofs, School Science and Mathematics, 99(8), 438-444.

Miyazaki, M. (2000). Levels of proof in lower secondary school mathematics. Educational Studies in Mathematics, 41(1), 47-68.

Moore, R. C. (1994) Making the transition to formal proof. Educational Studies in Mathematics, 27, 249-266.

National Council of Teachers of Mathematics (NSTM). (2000). Principles and standards for school mathematics. Reston, VA: Author.

Nunnally, J. (1978). Psychometric Methods. New York: McGraw-Hill Book Co.

Ören, D. (2007). Onuncu sınıf öğrencilerinin geometrideki ispat şemalarının bilişsel stilleri ve cinsiyetlerine göre incelenmesine yönelik bir çalışma. Yayınlanmamış yüksek lisans tezi, Orta Doğu Teknik Üniversitesi Fen Bilimleri Enstitüsü, Ankara.

Pehlivan, K. B. (2010). A study on prospective teachers' learning styles and their attitudes toward teaching profession. Elementary Education Online, 9(2), 749-763.

Recio, A. M. ve Godino, J. D.(2001). Instutional and Personal Meanings of Mathematical Proof, Educational Studies in Mathematics, 48(1), 83-89.

Sarı, M., Altun, A., ve Aşkar, P. (2007). Üniversite öğrencilerinin analiz dersi kapsamında matematiksel kanıtlama süreçleri: Örnek olay çalışması. Ankara Üniversitesi Eğitim Bilimleri Fakültesi Dergisi, 40(2), 295-319.

Solomon, Y. (2006). Deficit or difference? The role of students' epistemologies of mathematics in their interactions with proof, Educational Studies in Mathematics, 61(3), 373-393.

Sünbül, A. M. (2004). Düşünme stilleri ölçeğinin geçerlik ve güvenirliği. Eğitim ve Bilim, 29(132).

Tall, D. (1995). Cognitive development, representations and proof. In Proceedings of the conference Justifying and Proving in School Mathematics (Vol. 27, p. 38).

Tufan, F. (2016). Öğrenme stillerinin ve matematik dersine yönelik tutumların matematik dersinin başarısı üzerine etkisi. Yayınlanmamış yüksek lisans tezi, Necmettin Erbakan Üniversitesi Eğitim Bilimleri Enstitüsü, Konya. 